\title{
SAMOPROCJENA OSOBA S PROBLEMIMA U PONAŠANJU O UČINKOVITOSTI HAGIOTERAPIJE
}

\author{
Bruno Matijašević - Toni Maglica
}

Osnovna škola Lotrščak, Zagreb

UDK: 615.852:316.624

bruno.matijasevic6@gmail.com

Sveučilište u Splitu

Filozofski fakultet

https://doi.org/10.34075/cs.56.2.3

Izvorni znanstveni rad

tmaglica@ffst.hr

Rad zaprimljen 8/2020

\section{Sažetak}

Duhounost, religija i religioznost $u$ sve većem broju empirijskih istraživanja navode se kao snažan zaštitini čimbenik za mentalno zdravlje, prevenciju i tretman problema u ponašanje te doprinos općem zdravlju pojedinaca. Cilj ovog istraživanja bio je steći uvid u hagioterapijsku duhounost te uturditi koje elemente hagioterapije osobe s problemima u ponašanju, koje su se uključile u tretman, procijenjuju učinkovitima. U istraživanju se koristila kvalitativna metodologija te su podaci analizirani tematskom analizom. Dubinski intervjui napravljeni su sa 6 sudionika oba spola koji su uključeni u hagioterapiju. Uz velik broj metoda i tehnika rada koji se inače koriste u savjetovanju osoba s problemima u ponašanju, sudionici su posebno učinkovitima istaknuli hagioterapijske pristupe koji se temelje na praštanju, kajanju, fokusu na „dobro“, na slobodu i čovjekovu vrijednost te meditaciju.

Ključne riječi: problemi u ponašanju, hagioterapija, duhounost, zaštitni čimbenici

\section{UVOD}

Ponuditi jednoznačnu definiciju problema u ponašanju velik je izazov za znanstvenike i praktičare koji se bave ovim područjem. Za potrebe ovog rada koristi se jedna od recentnijih u području društvenih znanosti, a to je da problemi u ponašanju predstavljaju „krovni pojam za kontinuum oblika ponašanja od jednostavnijih, manje težine i opasnosti/štetnosti za sebe ili druge, do onih propisima definiranih i/ili sankcioniranih i, često, težih po posljedicama i potrebama za tretmanom ${ }^{1}$.“ Također, to je „središnji pojam koji supsumira

$1 \quad$ Nivex Koller-Trbović - Antonija Žižak. - Ivana Jeđud Borić, Standardi za terminologiju, definiciju, kriterije i način praćenja pojave poremećaja u ponašanju djece $i$ 
ekstremnije oblike tog fenomena na oba smjera, od rizičnih ponašanja preko teškoća pa do poremećaja u ponašanju. “2

Jedna od raširenijih teorija objašnjavanja razvoja i ponašanja pojedinca, koja se onda koristi i u objašnjavanju problema u ponašanju jest ekološko-sustavna teorija koja pridonosi boljem razumijevanju pojedinca i okoline u kojoj se pojedinac nalazi ${ }^{3}$. Ekološki model objašnjava četiri sustava okruženja koji utječu na čovjeka i njegovo funkcioniranje pa tako i na probleme $u$ ponašanju. Međutim, okruženje koje utječe na razvoj pojedinca nije ograničeno samo na neposrednu okolinu nego je prošireno i na poveznice i odnose među sustavima koji okružuju pojedinca. Najbliži sustav koji utječe na pojedinca jest mikrosustav koji ima najneposredniji i najraniji utjecaj te u njega spadaju uloge, aktivnosti i međuljudski odnosi koje pojedinac doživljava u nekom fizičkom okruženju. Mikrosustav nije konstantan, već se mijenja odrastanjem pojedinca pa tako uključuje obitelj i ostale osobe koje u razvoju čovjeka imaju važnu ulogu, ali i dječji vrtić, školu, crkvu i druga okruženja. ${ }^{4}$ Nakon njega slijedi mezosustav, koji obuhvaća niz odnosa među mikrosustavima. Osim aktivnog sudjelovanja pojedinca u okolini, čimbenici koji utječu na čovjekov život proizlaze i iz situacija, trajnih stanja ili događaja na koje pojedinac nema utjecaj. Taj sustav naziva se egzosustav te u njega spadaju radno mjesto, socijalne usluge u zajednici i mediji. Sveobuhvatan sustav u kojemu se pojedinac razvija i u kojemu je aktivan sudionik naziva se makrosustav, a odnosi se na politike, ekonomiju, društvene uvjete, kulturne vrijednosti i nacionalne običaje, norme i zakone ${ }^{5}$.

Unutar ovih sustava-okruženja (baš kao i u samom pojedincu) te u njihovom međusobnom djelovanju nalaze se rizični i zaštitni čimbenici koji utječu na ponašanje i funkcioniranje pojedinca ${ }^{6}$. Rizični čimbenici definiraju se „kao obilježja, varijable ili opasnosti koje se mogu nalaziti u pojedincu i/ili okruženju, a koje s većom

mladih, Povjerenstvo za prevenciju poremećaja u ponašanju djece i mladih Vlade Republike Hrvatske, Zagreb, 2011, 12.

2 Isto, 12

3 Urie Bronfenbrenner, The Ecology of Human Development, Mass: Harvard University Press, Cambridge, 1979.

4 Jennifer Boemmel - Joan Briscoe, Web Quest Project Therory fact sheet of Urie Bronfenbrenner, National_louis University (2001), (9. svibnja 2001) http://chiron.valdosta.edu/ (pristupljeno: 7. kolovoza 2020.)

5 Urie Bronfenbrenner, The Ecology of Human Development...; Ross Vasta, Marshall M. Haith, Scott A. Miller, Dječja psihologija: moderna znanost, Naklada Slap, Jastrebarsko, 2005, 61.

6 Urie Bronfenbrenner, The Ecology of Human Development... 
vjerojatnosti predviđaju razvoj problema u ponašanju“7. Oni pojačavaju vjerojatnost prvog pojavljivanja problema, napredovanje prema vrlo ozbiljnom stanju te podržavanju problematičnog stanja ${ }^{8}$. Međutim, hoće li pojedinac razviti probleme u ponašanju ne ovisi samo o rizičnim čimbenicima. Naime, ni jedan čimbenik rizika ili nepovoljna situacija sami za sebe ne mogu biti „odgovorni“ za negativne ishode, odnosno probleme u ponašanju, već je uvijek riječ o procesu složenih interakcija između više čimbenika rizika, ali i čimbenika zaštite. Zaštitni čimbenici pomažu pojedincu u ublažavanju rizika te imaju zadaću preveniranja procesa koji pokreću rizično ili problematično ponašanje te preveniranja pojavljivanja čimbenika rizika ${ }^{9}$. Religioznost i duhovnost u mnogim se istraživanjima mentalnog zdravlja, prevencije i tretmana problema u ponašanju navode kao zaštitni čimbenici za mentalno zdravlje pojedinca.

\section{DuhOVNOST I RELIGIOZNOST KAO ZAŠTITNI ČIMBENICI}

Duhovnost, religija i religioznost oduvijek su u središtu zanimanja čovjeka pa ne iznenađuje, stoga, kako se veliki broj praktičara i znanstvenika-istraživača bavi ovom temom. S obzirom da se u ovom radu pojmovi duhovnost i religioznost međusobno isprepleću, važno je naglasiti kako ovi pojmovi nisu istoznačni. Pojam duhovnost odnosi se na traženje smisla kroz odnos s Bogom, iskustvo odnosa s njim, na vezu između tog odnosa i traženja smisla ${ }^{10}$; religija podrazumijeva skup učenja, znanja, rituala, obreda i praksi koji se njeguju unutar zajednice vjernika ${ }^{11}$. Duhovnost se tiče više osobnoga

7 Toni Maglica, Obilježja roditeljstva i odnos roditelja prema kockanju kao prediktori kockanja muške djece. Doktorska disertacija, Zagreb, Sveučilište u Zagrebu, Edukacijsko-rehabilitacijski fakultet, 2017, 10; Patricia J. Mrazek - Robert .J. Haggerty, Reducing Risk for Mental Disorders: Frontiers for Prevention Intervention Research, National Academy Press, Washington DC, 1994, 127-191.

8 Josipa Bašić - Martina Ferić, Djeca i mladi u riziku- rizična ponašanja, (u) Josipa Bašić - Nivex Koller-Trbović - Slobodan Uzelac (ur). Poremećaji u ponašanju: pristupi i pojmovna određenja, Edukacijsko rehabilitacijski fakultet Sveučilišta u Zagrebu, Zagreb, 2004, 57-71.

9 Josipa Bašić, Teorije prevencije: prevencija poremećaja u ponašanju i rizičnih ponašanja djece i Mladih, Školska knjiga. Zagreb, 2009; Martina Ferić, Obitelj kao čimbenik rizika i zaštite za razvoj poremećaja u ponašanju djece i mladih, Hrvatska revija za rehabilitacijska istraživanja, 38 (2002), 1, 13-24.

10 David R. Hodge - Paul Cardenas - Harry Montoya, Substance use: Spirituality and religious participation as protective factors among rural youths, Social Work Research, 3 (2001) 25, 153-161.; Zdravka Leutar - Ivan. Leutar, Religioznost i duhovnost u socijalnom radu, Crkva u svijetu, 4 (2001), 1, 85, 107.

11 Isto, 153-161, 107. 
doživljaja, a religija pak osobnoga i društvenoga doživljaja ${ }^{12}$. Osoba koja je religiozna ne mora nužno biti i duhovna, dok u rjeđim slučajevima nalazimo da osoba koja je duhovna nije i religiozna.

Kako se ranije navelo, kroz povijest, a i danas ove su teme predmet brojnih istraživanja. To ne iznenađuje, jer duhovna je dimenzija sastavni dio čovjeka ${ }^{13}$. Istraživanja vezana za duhovnost počinju već u 19. stoljeću, kada Emile Durkheim, istražujući suicidalne pojedince, navodi pozitivan utjecaj duhovnosti i religioznosti na njih $^{14}$. Novija istraživanja otkrivaju kako duhovnost, religija i religioznost imaju pozitivan utjecaj na razvoj zdravstvenih karakteristika osobe ${ }^{15}$ i na pozitivan razvoj osobe $u$ cjelini ${ }^{16}$. Sve je veći broj istraživanja koja pokazuju povezanost duhovnosti i religioznosti s poboljšanim zdravstvenim ishodima, napose u dijelu mentalnog zdravlja, depresivnih simptoma, nižeg rizika od samoubojstva, smanjenog mortaliteta te povećane kvalitete života ${ }^{17}$. Nadalje, duhovnost i življenje u skladu s naukom vjere predstavljaju svojevrsnu zaštitu od konzumacije opojnih sredstava ${ }^{18}$. Neka istraživanja govore o negativnoj povezanosti učestalosti odlazaka na misu i ovisnosti o alkoholu, kao i o kasnijem inicijalnom uključivanju u konzumaciju alkohola onih

12 Nikolina Nedjeljković, Duhounost kao čimbenik otpornosti. Specijalistički rad, Zagreb, Sveučilište u Zagrebu, Edukacijsko-rehabilitacijski fakultet, 2016, 18.

13 Tomislav Ivančić, Hagioterapija u susretu s čovjekom, Zagreb, Teovizija, 2015, 42.

14 Emile Durkheim, Suicide: A study in sociology, Free Press, New York, 1857, 160-170.

15 Marjana Koščak, Prevencije poremećaja u ponašanju prema don Boscovu modelu, Kateheza : časopis za vjeronauk u školi, katehezu i pastoral mladih, 34 (2012) 1, 64-95; Ana C. Salgado, Review of Empirical Studies on Impact of Religion, Religiosity and Spirituality as Protective Factors, Journal of Educational Psychology, 2 (2014) 1, 144.

16 Ying Chen - Tyler J. Vanderweele, Associations of Religious Upbringing With Subsequent Health and Well-Being From Adolescence to Young Adulthood: An Outcome-Wide Analysis, American Journal of Epidemiology, 187 (2018) 11, 2355-2364.

17 Mira Klarin - Arkadiusz Krasicki, Religioznost i neke dimenzije psihološke dobrobiti kod mladih, Nova prisutnost, 18 (2020) 2, 229-243; Ying Chen - Tyler J. Vanderweele Associations of Religious Upbringing With Subsequent Health and Well-Being From Adolescence to Young Adulthood: An Outcome-Wide Analysis...2361; Tyler J. Vanderweele, Religion and health: a synthesis, In: John R. Peteet - Michael J. Balboni, Spirituality and Religion Within the Culture od Medicine: From Evidence to Practice. NY:Oxford University Press, New York, 2017, 357-402; Fernanda Carolina Gomes, Religion as a protective factor against drug use among Brazilian university students: a national survey, Official Journal of the Brazilian Psychiatric Association, 35 (2013) 2, 29-37.

18 Marjana Koščak, Prevencije poremećaja u ponašanju prema don Boscovu modelu..., 64-95. 
koji iskazuju religioznost $u$ ranom djetinjstvu ${ }^{19}$. Kad su u pitanju studenti, pojedina istraživanja pokazuju kako oni koji su iskazali da ne vjeruju u Boga konzumiraju više alkohola te oni kojima je vjera nevažna u većoj mjeri konzumiraju alkohol, duhan, marihuanu i halucinogene droge ${ }^{20}$. Religiozni studenti iskazuju i više razine subjektivne dobrobiti ${ }^{21}$.

\section{HAGIOTERAPIJA I NJEZIN PRISTUP PROBLEMIMA U PONAŠANJU}

Prof. Tomislav Ivančić, osnivač hagioterapije, navodio je kako čovjek egzistira na fizičkoj, psihološkoj i duhovnoj razini ${ }^{22}$. Hagioterapija u središtu svog djelovanja ima upravo duhovnu dušu te se smatra „metodom i putom k ozdravljenju čovjekove duhovne duše na temelju duhovnoga terapijskog postupka ${ }^{23}$." Polazište znanstvenog i terapijskog dijela hagioterapije jest duhovna dimenzija čovjeka koja skupa s fizičkom i psihičkom dimenzijom čini čovjeka u cjelini. Zdravlje duhovne dimenzije ovisi o okrenutosti prema bitku ili $\mathrm{Bogu}^{24}$. Ako pojedina osoba ima problema na duhovnoj dimenziji, onda se govori o manjku cjelovitosti ${ }^{25}$, koja je manifestirana na ostalim čovjekovim dimenzijama ${ }^{26}$. I Viktor Frankl pisao je kako se niz psihičkih bolesti može liječiti na temelju čovjekove duhovne dimenzije, i to egzistencijalnom analizom u kojoj se otkriva smisao ili frustriranost čovjekovog života ${ }^{27}$. Hagioterapija, pak, navodi sljedeće korake u liječenju duhovne dimenzije:

1. Kognitivna terapija: Kako bi se problemi na duhovnoj dimenziji uspješno liječili, pacijent pristupa upitniku i individual-

19 Michelle V. Porche i sur., Distal and Proximal Religiosity as Protective Factors for Adolescent and Emerging Adult Alcholoc Use, Religions, 6 (2015) 2, 365-384.

20 Patrick.S. Parfrey, The effect of religious factors on intoxicant use, Scand J. Soc. Med., 4 (1976) 3, 135-140; Ruth C. Engs, The drug-use patterns of helping-proffesion student sin Brisbane, Australia, Drug Alcohol Depend, 6 (1980) 4, 231-46: Jocelyn Turner-Musa - La'Shaunna Lipscomb, Spirituality and social support on health behaviors of african american undergraduates, AM J HEALTH BEHAV., 31 (2007) 5: 495-501.

21 Ahme Abdel-Khalek, Subjective well-being and religiosity in Egyptian college students, Psychol Rep., 108 (2011) 1, 54-8.

22 Tomislav Ivančić, Hagioterapija u susretu s čovjekom..., 42

23 Tomislav Ivančić, Hagioterapija - model terapijske antropologije, Nova prisutnost, 5 (2007) 1, 10.

24 Tomislav Ivančić, Roditelji, učitelji, učenici, Teovizija, Zagreb 2016.

25 Hans Urs von Balthasar, In der Fulle des Glaubens, Freiburg, Basel, Wien, Herder, 1981, 90.

26 Tomislav Ivančić, Roditelji, učitelji, učenici...

27 Viktor Frankl, Bog podsvijesti, Oko tri ujutro, Zagreb, 1980, 22. 
nom razgovoru nakon kojih se postavlja dijagnoza ${ }^{28}$. S istom se suočava i pacijenta, ali na kognitivnoj razini.

2. Aksiološka terapija: Uspjeh u liječenju problema na duhovnoj razini ovisi o pacijentovoj odluci za promjenom ${ }^{29}$.

3. Antropološka terapija: Posljednji korak razlikuje dva dijela pristupa pacijentu. Osoba koja prihvaća nauk Katoličke Crkve te ju se upoznaje s Božjom milošću, dok osoba koja ne prihvaća nauk Katoličke Crkve biva upoznata s filozofskim sinonimom za Boga, to jest bitkom ${ }^{30}$.

Navedeni postupci predstavljaju posredovanje duhovnog zdravlja te za čovjeka obrat u načinu življenja ${ }^{31}$.

\section{MetodologiJA}

\subsection{Cilj istraživanja i istraživačka pitanja}

Usprkos rastućem broju istraživanja u ovom području, duhovnost još uvijek ostaje neistražena, ne samo u području mentalnog zdravlja nego i u drugim domenama ${ }^{32}$. Naime, većina istraživanja fokusirana je na povezanost duhovnosti i mentalnog zdravlja te su se uglavnom istraživali konstrukti zadovoljstva životom, sreće i depresivnih stanja. Međutim, nedostaju istraživanja stavova, vjerovanja i iskustava pojedinaca, kao i utjecaj religije kao agensa terapeutskog rada $\mathrm{s}$ problemima $\mathrm{u}$ ponašanju ili patologijom ${ }^{33}$.

S obzirom na navedeno, cilj ovog istraživanja jest steći uvid u elemente hagioterapijske duhovnosti koje su osobe s problemima $u$ ponašanju procijenile učinkovitima tijekom primanja pomoći. Dakle, ispitivalo se njihovo subjektivno iskustvo tijekom hagioterapijskog tretmana.

U skladu s navedenim artikulirana su dva istraživačka pitanja:

1. Koji su motivi sudionika za uključivanjem u hagioterapiju?

2. Koje elemente hagioterapije sudionici procjenjuju posebno djelotvornima?

28 Tomislav Ivančić, Hagioterapija-model terapijske antropologije..., 12.

29 Tomislav Ivančić, Hagioterapija u susretu s čovjekom..., 285-290.

30 Isto, 275.

31 Tomislav Ivančić, Hagioterapija - model terapijske antropologije..., 16.

32 Jeff Levin, Religion and Mental Helth: Theory and Research, Internationaln Journal of Applied Psychoanalytic Studies, 7 (2010) 2, 102-115.

33 Isto..., 106 


\subsection{Postupak provedbe istraživanja}

U svrhu dobivanja što konkretnijih i relevantnijih podataka korištena je metoda polustrukturiranog intervjua prema smjernicama Jacoba i Furgersona ${ }^{34}$. Razgovor između ispitivača i sudionika intervjua, uz njihov pristanak, snimao se diktafonom. Pitanja u intervjuu bila su otvorenog tipa te su na njih sudionici odgovarali opisujući vlastita iskustva, promišljanja i/ili stavove. Postavljena su sljedeća pitanja: Zbog kojih ste se problema javili na hagioterapijske tretmane? Koja je motivacija za uključivanje u hagioterapiju? Koliko često ste dolazili, gdje, kojom dinamikom, u kojem vremenskom razdoblju, tj. koliko dugo, koliko otprilike traje taj susret? Kako su izgledali ti susreti? Što Vam se čini koji je dio hagioterapije bio posebno djelotvoran za Vas?

Svaki intervju zahtijevao je pripremu intervjuera te informiranje sudionika o cilju i svrsi rada, načinu rada, traženju dobrovoljnog pristanka, njihovoj anonimnosti te o mogućnosti odustajanja u bilo kojem trenutku. Svi intervjui su, uz dozvolu sudionika, snimani te su nakon toga transkribirani.

\subsection{Uzorak sudionika}

Uzevši u obzir da objekt uzorkovanja nisu pojedinci, već njihova iskustva ${ }^{35}$, kontaktirali smo voditeljicu Centra za hagioterapiju, upoznali je sa svrhom i ciljem rada, te je ona u konačnici predložila 6 kandidata koji su bili uključeni u hagioterapijske tretmane. Nakon kontakta i privole predloženih kandidata, svih 6 je pristalo na intervju, tako da konačan uzorak ovog kvalitativnog istraživanja iznosi 6 sudionika. Kako su sudionici imali različita životna iskustva i različite probleme u ponašanju, može se kazati kako uzorak odgovara maksimalnoj varijaciji.

\subsection{Istraživački pristup i analiza podataka}

Respektirajući cilj istraživanja, kao i istraživačka pitanja, korištena je kvalitativna metodologija, a podatci su analizirani tematskom analizom sukladno fazama koje su predložili Braun i Clarke ${ }^{36}$.

34 Stacy A. Jacob - S. Paige Furgerson, Writing interview protocols and conducting interviews: tips for students new to the field of qualitative research. The Qualitative Report, 42 (2012) 17, 1-10.

35 Margarete Sandelowski, Sample size in qualitative research. Research in Nursing \& Health, 18(1995) 2, 179-183.

36 Virginia Braun - Victoria Clarke, Using thematic analysis in psychology, Qualitative Research in Psychology, 3 (2006) 2, 77-101. 
Dvojica istraživača, autora ovog rada, individualno su bilježili kodove unutar transkripata te su ih u konačnici usporedili. Složili su se u najvećem broju kodova te su na osnovi prepoznatih kodova artikulirali teme. Teme i kodovi dobiveni tematskom analizom koji će biti prikazani u rezultatima istraživanja derivirani su iz podataka (data driven) ${ }^{37}$.

\section{REZULTATI}

Podatci dobiveni kodiranjem razvrstani su u 6 tema. Radi jednostavnijeg pregleda $\mathrm{u}$ Tablici 1 . nalazi se prikaz tema s pripadajućim kodovima, dok će se dalje u tekstu svaka tema deskriptivno razraditi te potkrijepiti citatima sudionika.

Tablica 1. Teme i pripadajući kodovi

$\begin{array}{ll}\text { Tema } & \text { Kodovi } \\ \text { Problemi u ponašanju } & \text { eksternalizirani } \\ & \text { internalizirani } \\ \text { Iskustva iz prošlosti kao } & \text { školski čimbenici } \\ \text { rizični čimbenici } & \text { biološki čimbenici } \\ \text { individualni čimbenici } & \text { obiteljski čimbenici } \\ \text { Motivacija za tretmanom } & \text { preporuka bližnje osobe } \\ & \text { problem kao motiv } \\ & \text { individualni rad } \\ \text { getode rada } & \text { grupni rad } \\ & \text { čovjek kao instrument promjene } \\ & \text { učenje iz iskustva drugih } \\ & \text { praktična primjena naučenog } \\ \text { kontinuitet } \\ \text { prepoznavanje problema } \\ \text { izražavanje emocija } \\ \text { savjetovanje } \\ \text { samorefleksija }\end{array}$

37 Helene Joffe ,Thematic Analysis, u: David Harper - Andrew R. Thompson (ur.), Qualitative Research Methods in Mental Health and Psychotherapy: A Guide for Students and Practitioners, Chichester: Wiley-Blackwell, 2011, 209-223. 


\begin{tabular}{|c|c|}
\hline $\begin{array}{l}\text { Specifični elementi } \\
\text { hagioterapije }\end{array}$ & $\begin{array}{l}\text { praštanje } \\
\text { kajanje } \\
\text { „dobro“ kao element promjene } \\
\text { preispitivanje kroz meditaciju } \\
\text { sloboda } \\
\text { čovjekova vrijednost }\end{array}$ \\
\hline Ishodi tretmana & $\begin{array}{l}\text { odsutnost simptoma } \\
\text { osobni rast }\end{array}$ \\
\hline
\end{tabular}

1. tema: Problemi u ponašanju

Prva od tema koja je dobivena obradom kodova jesu „Problemi u ponašanju“. Sudionici su iskazivali veliki broj problema u ponašanju zbog kojih su se javili na hagioterapijske tretmane. Također, razvidno je iz intervjua kako se navedeni problemi u ponašanju manifestiraju kroz internalizirane i eksternalizirane oblike.

Internalizirani problemi u ponašanju: „Na hagioterapijske probleme sam se javila zbog osjećaja osamljenosti i odbačenosti..."(I/3); „Osjetia san nedostatak smisla u životu..." (I/6)

Eksternalizirani problemi u ponašanju: „Plus šta ono, bio san ima malo agresivnost, zna san se tu potuć pa san ima nekih prijava na policiji zbog nanošenja fizičkih povreda za remećenje javnog reda $i$ mira.“ (I/4), „Pa javio sam se zbog problema $\mathrm{s}$ nasilnim ponašanjem.." (I/1)

2. tema: Iskustva iz prošlosti kao rizični čimbenik

Podatci koji su dobiveni intervjuiranjem ukazivali su na značajan utjecaj prošlosti sudionika na razvoj i etiologiju njihova problema. Zapravo, njihova prošlost te pojedine situacije iz prošlosti predstavljale su rizične čimbenike čija je prisutnost, uz ostale čimbenike, dovela do razvoja problema u ponašanju. Navedeni rizični čimbenici primijećeni su kako u samom pojedincu, tako i u njegovoj okolini. Shodno tome, klasificirani su u školske, biološke, individualne i obiteljske rizične čimbenike.

Školski čimbenici: „Ima san problema i sa nekin drugin bolestima ima san astmu, ima san disleksiju i kroz školu su mi se dica rugala." (I/4); „Kroz osnovnu školu sam od strane društva doživjela odbačenost i neprihvaćanje zbog izgleda i... nekako zbog financije, jer ko ima para...s njima se družila, a kod mene to nije bila situacija..." (I/3)

Biološki čimbenici: „Ima san genetsku predispoziciju za suicidalnost, materin brat se ubio, rođak prvi isto. I ja san osjeća...kako da 
kažen...suicidalnu sklonost, traženje smisla, pesimističnu stvarnost koja je izgledala grozno i nesigurno...koju san nadiša kroz hagioterapiju. "(I/4)

Individualni čimbenici: „...javio sam se zbog problema s nasilnim ponašanjem zatim zbog problema sa neodređenim strahom, anksioznošću koja me iz dana u dan pratila u to vrijeme...šta sam primjećiva da sam puno manje radostan ili sretan od nekakvog prosjeka ljudi koje sam susretao u svom životu. “ (I/1); „Evo, zbog neke nesigurnosti, nekog straha, nekog pesimizma cilo vrime, uvik san se nekako boja drugih ljudi, nikako nisan tija ulazit u neka prijateljstva ili nešto drugo. Ima san, tu teško. Na poslu san funkcionira, posa mi nebi traja duže do 2 miseca..." (I/4)

Obiteljski čimbenici: „...ima bi nekih problema u familiji...“(I/4); „...kako je došla ta situacija u familiji, zakuvala, došla do zida, nisan više zna šta bi. “(I/4)

\section{3. tema: Motivacija za tretmanom}

Sudionici su u intervjuima iskazali širok spektar događaja i emocija te osoba koje su ih motivirale na traženje pomoći, odnosno uključivanje u tretman. Nakon kodiranja dobivene su dvije teme, i to: „Preporuka bližnje osobe“ $i$ „Problem kao motiv“. Ono što je zanimljivo jest da je kod svih sudionika neka važna ženska osoba bila ključna u motiviranju za uključivanje u tretman.

Preporuka bližnje osobe: „Nekako mater to spomenila... “ (I/4); „..moja sestra je već bila u Zajednici molitva i riječ koja se bavila hagioterapijom pa sam vidio pozitivnog utjecaja u njenom životu i mislio sam da bi i meni moglo koristit..." (I/6)

Problem kao motiv: „Znači, motivacija mi je bila što sam u jednom trenutku napravio jedan čak fizički nasilan čin prema djevojci $s$ kojom sam tada hodao. I to me u principu zaprepastilo, jer nikad nisam mislio da bi to bio kadar napravit. “ (I/ 1); „Ništa posebno, kako je došla ta situacija u familiji, zakuvala, došla do zida, nisan više zna šta bi. “(I/4)

\section{4. tema: Metode rada}

Iz dobivenih podataka razvidno je kako su se tijekom tretmana koristile različite metode i pristupi u rješavanju specifičnih problema u ponašanju. U temi „Metode rada“ razvidni su mnogobrojni i različiti pristupi te se ova tema sastoji od kodova: grupni rad, individualni rad, čovjek kao instrument promjene, učenje iz iskustva drugih, kontinuitet, praktična primjena, prepoznavanje problema, izražavanje emocija, savjetovanje te samorefleksija. Grupni rad 
odnosi se na hagioterapijski tretman koji se realizira u grupi, dok individualni pristup predstavlja rad ,jedan na jedan“ te posvećenost hagioasistenta jednom čovjeku i njegovom jedinstvenom slučaju. Iščitavajući transkripte, moglo se vidjeti kako su sudionici navodili čovjeka, pojedinca, hagioasistenta koji ih je poticao na promjenu, kao i učenje iz iskustva drugih ljudi s kojima su bili u grupi, što se i inače smatra velikom prednošću grupnog rada. Osim navedenoga, veći broj sudionika govori o važnosti „praktične primjene naučenog“. Naime, sve o čemu se razgovaralo tijekom tretmanskih susreta sudionici su bili pozvani primijeniti u svakodnevnom životu. Dalje $\mathrm{u}$ tekstu dat će se primjeri navoda sudionika za svaki pojedini kod unutar ove teme.

Grupni rad: „Susretigrupni, ka šta san već i rekla, bili su mi informativnog karaktera sa dijelom meditacije koji bi me amo reć drma." (I/5); „...ti tjedni susreti izgledali su kao jedno predavanje u kojem bi uvijek dakle tijekom tog perioda predavanja bile znači, neka razdoblja od pet minuta gdje čovjek stani i razmisli o onome što je izrečeno. "(I/2)

Individualni pristup: „Individualne susrete..., uvik nešto novo otkriješ, al i dalje san ostajala prazna is nekim pitanjima $i$ upitnicima gdje sam ja tu. Prvi susret je bija onako dosta, više su pitanja bila na meni, kao zašto ste opće došli na hagioterapiju, kad van se prvi put to desilo više san ja pričala da bi se uturdilo šta se opće desilo. Na sljedećim susretima bi pričao hagioterapeut, davao mi upute kako doć do zdravlja..." (I/5)

Čovjek kao instrument promjene: „Video predavanja prof. Ivančića su me motivirala da više saznam o samoj hagioterapiji i već sama ta videa su mi pomogla. “(I/3); „... išla sam u prof. Ivančića na tribine u Zagrebu i ostalo mi je nešto šta je super..." (I/5); “...bio na misi koju je on vodio i bila mi je jako dobra njegova propovijed pa mi je i to nekako bilo prihvatljivo. "(I/1)

Učenje iz iskustva drugih: „...vidio sam da su neki drugi promijenili koji su imali teške probleme...znači da postoji mogućnost da može bit bolje..." (I/1); „...te bi i voditelji iznosili svoja iskustva iz života $i$ kako im je hagioterapija pomogla. Njihova iskustva iz života bi $i$ mene poticali da ne odustanem od sebe..." (I/3)

Praktična primjena naučenog: „Za mene posebno djelotvoran dio hagioterapije je bio dakle što je u njoj bitna ta praksa...ona potiče na praksu. Za mene je to bilo ključno.“ (I/2); „Oni bi u principu pričali kako nadilaziti neke svoje patnje $i$ kako to provoditi u praksi, iša san tu više prikupljat informacije na neki način $i$ onda kad bi iša doma to bi proba provest i onda bi se vidili pozitivni utjecaji.“(I/6); „Neke stvari koje bi čuo na susretima bili su mi zanimljivi pa bi to još uz knjige počeo provoditi na sebi." (I/4) 
Kontinuitet tretmana: „Grupni susreti su bili svaki tjedan , znači jedan puta tjedan u razmaku od 5 mjeseci...“ (I/ 1); „Dolazila sam na grupne terapije jednom tjedno po sat ipo vremena kroz period od šest mjeseci." (I/3)

Prepoznavanje problema: „..čovjek onda mogao prepoznati, vidit u čemu je problem, vidit di je izvor problema i kako ga riješiti... " (I/ 1); „...osvijestila san taj problem..." (I/5); „Mogla san uočavat koji su to obrasci ponašanja koji su mene doveli u neke situacije, nije se sve to trebalo desiti kako se desilo..." (I/3)

Izražavanje emocija: „...prvo je bilo bitno iz sebe izbaciti nekakvu mržnju i negativnost u sebi koju sam nosio , koju su mi nanijeli drugi ljudi." (I/1)

Savjetovanje: „...pa davao je neke konkretne savjete i dijagnoze, znači u kojima se čovjek onda mogao prepoznati, vidit u čemu je problem..."(I/1); „...Davala mi upute kako doć do zdravlja..." (I/5)

Samorefleksija: „Profesor koji bi nas vodio uputio bi nas da stanemo i promislimo o tome što je rečeno,... bile su tako dvije do tri vježbe od možda tri, četiri, pet minuta gdje bi zapravo ti nad tim promišljao, vidio gdje sebe u tom pronalaziš..."(I/2); „...postavljaje pred mene neka pitanja koja... kako bi reka... potaknu da u dubini sebe... neka pitanja, neke stvarnosti koje su bile zdravo za gotovo, preispitaš ponouno. " (I/5)

Prihvaćanje sebe: „...Počela sam drugačije gledati na sebe, prihvaćati sebe i zavoljeti se... "(I/3); „...Prihvaćanjem sebe doša san do tog nekog iskustva kojeg san prije tražio priko nekih drugih lažnih stvari." (I/4)

\section{5. tema: Specifični elementi hagioterapije}

Iz dobivenih iskustava $\mathrm{s}$ hagioterapijskih tretmana $\mathrm{u}$ intervjuima su se mogli iščitati specifični elementi rada koje smo svrstali u temu „Specifični elementi hagioterapije“. U ovu temu uvrstili smo sljedeće kodove: praštanje, savjetovanje, kajanje, „dobro“ kao element promjene, sloboda, čovjekova vrijednost. Neki od navedenih kodova univerzalni su za humanistički pristup savjetovanju pojedinca, dok se neki više odnose na specifične teme duhovnosti i religije, poput kodova praštanja i kajanja.

Praštanje: „Tu je zato posebno bilo bitno praštanje. Znači praštanje kao terapija i spoznaja da praštanje nije nešto čime ja oslobađanjem... čime se ja ponizujem pred nekim koji je meni zlo napravio, da to nije neki sramotan čin u kojem ja odričem svog ponosa i tako nešto. Već je to izlaz u slobodu od onog zla kojeg mi je taj čovjek nanio to je kao nekakav duhouni imunitet, to mi je puno pomoglo. “ (I/1); „Isto 
mi je pomoglo oprostiti obitelji i prijateljima koji su mi nanosili, kao amo reć, bol. Također, i oprostiti i sebi za neke stvari koje mislim da sam pogrešno nekad napravila. Onda, drugi polaznici u grupi, mislim da dio koji je njima pomogao i koji bi moga pomagat i ostalima je opraštanje drugima, ali samima sebi. To mislim da je nekako, taj oprost koji se naglašavao u hagioterapiji izrazito djelotvoran. " (I/3)

Kajanje: „Osim praštanja, mučile su me neke loše stvari koje sam ja napravio u prošlosti $i$ kojih nekako nisam mogo oslobodit. Znači, čim bi se ja sjetio tih stvari, uvijek $u$ meni bi... s njima sam bio vezan iznutra, nekako sam sebe cijenio manje zbog toga, mislio sam da nema izlaza, a njih sam se oslobodio također znači kajanjem. Prizna bi da sam učinio to zlo i ono što je bilo jako bitno je to povjerenje i vjera koju sam dobio da se mogu promijenit... " (I/1)

„Dobro“ kao element promjene: „Značija sam patio od strahova, na neki način obrnuto od straha je povjerenje, kad ti imaš povjerenje $u$ dobro, onda u principu nema mjesta za strah. Ako ti stalno misliš da će bit loše, da su ti ljudi oko tebe neprijatelji, da je sve negativno ... ono što su ono meni, znači hagioasistenti donijeli je povjerenje $u$ dobro, to nije neko pozitivno mišljenje, nego jedna zapravo stvarnost koja je u njima samima i na koju se čovjek može oslonit zapravo i izać zauvijek iz tog jednog bolesnog stanja, npr. straha. “(I/1)

Preispitivanje kroz meditaciju: „...sa dijelom meditacije koji bi me amo reć drma. “(I/5); „...bile su tako dvije do tri vježbe od možda tri, četiri, pet minuta gdje bi zapravo ti nad tim promišljao, vidio gdje sebe $u$ tom pronalaziš, možda šta bio mogao primijeniti od toga što je izrečeno... grupe rade na sličan način samo što je kraće gdje bi bila možda jedna takva meditativna vježba..." (I/2)

Sloboda: „...opet ti se intelektom objasni, razumski kako smo u svijetu koji je u patnji i koji ima slobodu izbora i koji... kako bi rekla... da nitko tu slobodu čovjekovu ni sam Stvoritelj neće oduzeti..." (I/5); „Mogla sam nekako u slobodi svojoj međuljudske odnos živit." (I/2)

Čovjekova vrijednost: „Drugo još što bi rekla za mene što je bilo strašno važno, to je što ona svakog čovjeka vidi kao vrijednog... "(I/2); „...uz poticaj voditelja dolazila do zaključka da vrijedim više od pohvala ljudi, da sam vrijedna i voljena bez obzira osvajala ja medalje i bila najbolja ili ne. "(I/3)

\section{6. tema: Ishodi tretmana}

Temeljitom analizom intervjua dali su se iščitati podatci o kvalitetnim ishodima nakon hagioterapijskih tretmana. Kvalitetni, pozitivni ishodi mogu se klasificirati u dva područja, i to: odsutnost simptoma i osobni rast sudionika. Odsutnost simptoma sudionika 
odnosi se na ishode kod kojih je došlo do nestanka simptoma. Problem zbog kojeg su došli nije se više manifestirao. No kod određenih sudionika dogodio se i dodatan osobni rast, dodatna kvaliteta života, napose u području ponašanja i emocija.

Odsutnost simptoma: „...Više ne lutan, više nisan ka neki brod koji luta i ne zna di ide. “(I/4); „...bio san otvoren za druge ljude, lakše san prihvaća sebe i bila je neka pozitivnija slika sebe i perspektiva budućnosti, nije više bilo tako beznadno, krenilo je to naprid nekako već nekih pola godine-godinu. " (I/4)

Osobni rast: „U hagioterapiji taj uzrok sam rješavala tako što sam sebe prihvaćala $i \mathrm{kad}$ sam zavoljela i prihvatila sebe, kad sam shvatila da sam vrijedna i dragocjena osoba meni više nisu bili potrebna poštivanja drugih ljudi i potreba da me se cijeni u društvu. Ja sam samu sebe cijenila $i$ voljela a samim time su me i drugi voljeli. "(I/3); „...da san nasta od ljubavi i da sam voljen, to mi je značilo, $i$ da iman neki temelj na koji se mogu osloniti i da moja želja za ljubavi može biti ispunjena neovisno o okolnostima." (I/6)

\section{RASPRAVA}

Hagioterapijska intervencija, bilo tretmanska bilo preventivna, uključuje rad na duhovnoj dimenziji čovjeka. Iako se u suvremenoj literaturi može naći duhovnost kao zaštitni čimbenik ${ }^{38}$, mali broj istraživanja, prema saznanjima autora ovog rada, ulazi u „dubinu“ te duhovnosti. Što konkretno stoji iza tog zaštitnog čimbenika, koje su to aktivnosti, ponašanja čovjeka, koje intervencije? Ovaj rad dijelom je odgovorio na neka od navedenih pitanja fokusirajući se na elemente hagioterapijskih intervencija u radu s ljudima koji manifestiraju probleme u ponašanju.

U odnosu na prvo istraživačko pitanje kojim se željelo utvrditi razloge traženja pomoći i uključivanja u hagioterapiju rezultati su pokazali kako su se sudionici uključili zbog vlastitih specifičnih internaliziranih i eksternaliziranih problema u ponašanju. Osim osjećaja preplavljenosti problemima važnu ulogu, u smislu potpore uključivanju i traženju pomoći, imale su ženske figure iz njihovih bliskih okruženja. Većina sudionika navodi majku, sestru ili prijateljicu kao osobe koju su inicirale traženje pomoći.

Uz to, ovo istraživanje potvrdilo je postojeće teorije kako do problema u ponašanju dolazi kombinacijom rizičnih i zaštitnih čim-

38 Ying Chen - Tyler J. Vanderweele, Associations of Religious Upbringing With Subsequent Health and Well-Being From Adolescence to Young Adulthood: An Outcome-Wide Analysis..., 2360-2363. 
benika koji se nalaze u pojedincu, ali i njegovom okruženju. Tako sudionici ovog istraživanja iskazuju biološke (genetske) i individualne rizične čimbenike, ali i obiteljske i školske rizične čimbenike koji spadaju u čimbenike okruženja. Ovi nalazi u skladu su s brojnim klasifikacijama rizičnih čimbenika ${ }^{39}$.

U odnosu na ključno istraživačko pitanje, a to je što sudionici procjenjuju posebno djelotvornim $u$ hagioterapiji, dobiveni su vrijedni podaci koji govore u prilog nekim postojećim metodama rada koje se koriste u savjetovanju, ali i njihovoj isprepletenosti s elementima koji pripadaju domeni duhovnosti, u ovom slučaju hagioterapijskoj duhovnosti. Od uobičajenih metoda i tehnika rada za koje je znanost već utvrdila kako su djelotvorne u procesima pomaganja i savjetovanja pojedinaca s problemima u ponašanju i sudionici ovog istraživanja navodili su: savjetovanje (kombinacija individualnog i grupnog rada), kontinuitet u savjetovanju, učenje iz iskustva drugih ljudi, primjenjivanje iskustava stečenih tijekom savjetovanja u svakodnevnom životu, prepoznavanje problema, samorefleksija, izražavanje emocija te čovjek/stručnjak kao „instrument“ promjene ponašanja. U ovom dijelu „preklapanja“ savjetovanja i hagioterapije važno je naglasiti kako prepoznavanje i osvještavanje problema predstavlja ključan prvi korak u donošenju odluke za promjenom ponašanja. Govoreći hagioterapijskim rječnikom, važna je aksiološka terapija koja, nakon kognitivnog posvješcivanja problema, nastupa kao poticatelj promjene ${ }^{40}$.

Slično kao kod hagioterapije i u drugim oblicima savjetovanja samouvid i samosvijest predstavljaju ključne elemente rada. Samouvid se odnosi na razumijevanje nastajanja poteškoća, dok se samosviješću postiže bolji uvid u osjećaje i ponašanja koje osoba prije nije mogla prepoznati ${ }^{41}$.

Osim toga, dobiveni rezultati pokazali su kako izražavanje osjećaja ima važnu ulogu u procesu rada na sebi. Ljudi imaju potrebu doživjeti i razumjeti vlastite osjećaje kao i osjećaje drugih ljudi u okolini $^{42}$. Potiskivanje osjećaja može imati negativan utjecaj na oso-

39 James H. Williams - Charles D. Ayers - Michael W. Arthur, Risk and Protective Factors in Decelopment of Delinquency and Conduct Disorders, u: Mark Fraser (ur): Risk and Resilience in Childhood: An Ecological Perspective. NASW Press, 1997, 140-170.

40 Lela Crnak, Hagioterapijska ljekarna, Teovizija, Zagreb, 2016, 39.

41 John Mcleod, An introduction to counseling, Buckingham, Open University Press, 2001.

42 Gregory G. Maio - Victora M. Esses, The need for affect: Individual differences in the motivation to approach and avoid emotions, Journal of Personality, 69 (2001) 4, 583-615. 
be koje su zdrave, a izražavanje osjećaja u tom je pogledu izrazito poželjno ${ }^{43}$. Podatci dobiveni iz intervjua ukazuju kako su potisnuti osjećaji imali negativan utjecaj na sudionike te su dodatno produbljivali njihove probleme. Sudionici koji nisu izražavali osjećaje imali su problem s depresivnošću te su primjećivali manjak zadovoljstva vlastitim životom te pomanjkanje životne radosti. Istraživanje Lewisa i Haviland-Jonesa ${ }^{44}$ govori u prilog zaključku kako pojedinci koji vještije izražavaju vlastite osjećaje nemaju problema s depresivnošću, dok nasuprot njima pojedinci s manjkom vještina za izražavanje osjećaja imaju povećan problema s depresijom.

Elementi koji se posebno odnose na duhovnost te hagioterapijsku duhovnost, a sudionici su ih posebno isticali kao ključne u radu, jesu: praštanje, kajanje, „dobro“ kao element promjene, meditacija, sloboda i naglašavanje čovjekove vrijednosti. Praštanje i kajanje osnovni su elementi hagioterapije te ih sudionici navode kao bitne, u nekim trenutcima i presudne za njihov pozitivan razvoj. Crnak $^{45} \mathrm{u}$ svojim navodima kako posredovati duhovno zdravlje gotovo u svim vrstama liječenja problema u ponašanju naglašava upravo oprost i kajanje. Oprost je okrenut prema osobi koja mora sama sebi oprostiti te prema pojedincu ili grupi koji su je povrijedili. Kajanje kao terapija veže se za oprost loših postupaka iz prošlosti čovjeka samom sebi. Psihološki aspekt kajanja spominju Zeelenbeg i Pieters ${ }^{46}$ koji također smatraju kako kajanje, odnosno žaljenje za prošlim događajima koji su bili negativni pridonose pozitivnim promjenama i životnim okolnostima pojedinaca, što se u slučaju provedenih intervjua i pokazalo kao točno. Osobe uz poticaj hagioasistenta te uz prihvaćanje savjeta hagioasistenta osjećaju i iskazuju napredak. Poticaj na rast očituje se u samorefleksiji koja je također naglašena te u samom tretmanu ima značajan udio. Kod grupnog pristupa ona se očituje u meditativnom dijelu kada sudionici posvješćuju izrečeno u meditaciji, a onda i vlastito stanje u odnosu na meditaciju. Meditativni dio sadrži pitanja za koje Ivančić ${ }^{47}$ govori kako vode prema duhovnoj razini čovjeka; takva pitanja propituju čovjekov smisao i

43 James J. Gross, Emotional expression in cancer onset and progression, Social Science and Medicine, 28( 1989) 12, 1239-1248.

44 Michael Lewis - Jeannette Haviland-Jones, Handbook of emotions. The Guilford Press, New York, 2000.

45 Lela Crnak, Hagioterapijska ljekarna..., 21-22, 40.

46 Marcel Zeelenberg - Rik Pieters, Comparing Service Delivery to What Might Have Been: Behavioral Responses to Regret and Disappointment, Journal of Service Research, 2 (1999) 1, 1999, 86-97.

47 Tomislav Ivančić, Dijagnoza duše i hagioterapija... 
ostavljaju pitanja otvorenima kako bi osoba sama sebi mogla odgovoriti na njih, što je prema dobivenim podatcima ovog istraživanja dovelo do pozitivnih pomaka u tretmanu. Važnosti duhovne dimenzije i meditacije unutar duhovnosti naglašavaju psiholozi Chen i VanderWeele $^{48}$ u svojem istraživanju utjecaja duhovnosti na čovjeka te otkrivaju kako su njihovi sudionici pozitivno ocijenili meditativni dio unutar duhovnosti. Živjeti u skladu s naukom svoje vjere predstavlja snažan zaštitni čimbenik za pojedinca ${ }^{49}$.

U ovom istraživanju element hagioterapije koji se odnosi na osvještavanje vlastite vrijednosti pokazao se iznimno učinkovitim, posebice $u$ odnosu na internalizirane probleme $u$ ponašanju sudionika. Navedeno se uklapa u teorijska tumačenja terapija koja navode kako je posvješćivanje vlastite vrijednosti osobe bitno za oporavak i napredak u terapiji ${ }^{50}$. Ivančić ${ }^{51}$ ukazuje na problem zaboravljanja ljudskog dostojanstva i vrijednosti koje se vraća kroz hagioterapiju. Iz konteksta prevencijskih znanosti sa sličnim zaključcima pojavljuje se i Ajduković ${ }^{52}$, koja kaže kako čovjeku pozitivan osjećaj stvara saznanje tko je i što je on ili ona te da je bitno znati da je čovjek netko i nešto, to jest da ima svoju vrijednost neovisno o tome što zna ili može napraviti. Nadalje, hagioasistenti su poticali osobe koje su došle po pomoć da u svom životu naprave zaokret prema dobru, prema činjenju dobrih i ispravnih stvari. Takav poticaj hagioasistenata prepoznaje se kao pozitivan utjecaj na osobe koje su tražile pomoć. „Dobro“ u terapijskom smislu znači zaokret pacijenta prema pozitivnim promjenama u životu. Dobiveni podatci iz intervjua govore kako je pristup koji se odnosi na povjerenje u „dobro“ djelotvoran uz poticaj voditelja. Čineći dobra djela, pojedinac osjeća terapijski učinak duhovne dimenzije ${ }^{53}$.

48 Ying Chen - Tyler J. Vanderweele, Associations of Religious Upbringing With Subsequent Health and Well-Being From Adolescence to Young Adulthood: An Outcome-Wide Analysis..., 23-57.

49 Renata Franc - Ines Sučić - Vlado Šakić, Vrijednosti kao rizični i zaštitni čimbenici socijalizacije mladih, Diaconvesia (Đakovo) 21-22 (2009) 1-2, 139.

50 Lela Crnak, Hagioterapijska ljekarna...28.

51 Tomislav Ivančić, Dijagnoza duhoune duše i hagioterapija...

52 Marina Ajduković, Ekološki multidimenzionalni pristup sagledavanju činitelja rizika i zaštite u razvoju poremećaja u ponašanju djece i mladeži, u: Josipa BAŠIĆ, Josip Janković, Rizični i zaštitni čimbenici u razvoju poremećaja u ponašanju djece i mladeži, (ur.), Povjerenstvo Vlade Republike Hrvatske za prevenciju poremećaja u ponašanju, Zagreb, 2000, 47-62.

53 Lela. Crnak, Hagioterapijska ljekarna...9; Tomislav Ivančić, Dijagnoza duhoune duše i hagioterapija... 
I u konačnici rezultati ovog istraživanja pokazali su kako sudionici ishode hagioterapijskih pristupa procjenjuju pozitivnima, navodeći odsutnost simptoma problema zbog kojih su i potražili pomoć, ali navode i snažan osjećaj osobnog rasta tijekom i nakon hagioterapije. Kako je svaki sudionik imao specifičan problem u ponašanju, svakome je trebalo različito vremensko razdoblje da bi se postigla odsutnost simptoma te osobni rast u konačnici. Prema dobivenim podatcima u ovom istraživanju, svaki hagioterapijski susret dovodio je do pozitivnog ishoda kod sudionika. U ovom istraživanju njegovi sudionici nisu mogli točno odrediti koji je to dio ili trenutak u kojem je došlo do pozitivne promjene, što zapravo ukazuje na nedohvatljivost mjerenja duhovne dimenzije koja je sama po sebi teško mjerljiva, ako ne i nemjerljiva. U prilog ovoj tezi stoji izjava Erica Kandela ${ }^{54}$ koji naglašava kako se mjerljivost duhovne dimenzije čovjeka očituje u posljedicama na ostalim dimenzijama čovjeka, a koje su psihičke i fizičke naravi.

\section{ZAKLJUČAK}

Cilj ovoga rada bio je ispitati i razumjeti čimbenike hagioterapije duhovnosti koji pozitivno utječu na osobe koje se odluče potražiti pomoć i uključiti se u ovakav oblik tretmana. Rezultati ovog istraživanja, dobiveni dubinskim intervjuima, ukazuju na pozitivan utjecaj hagioterapije na probleme u ponašanju. Hagioterapija se dijeli na znanstveni i terapijski dio te se oslanja na prethodne znanstvene spoznaje dobivene $\mathrm{u}$ ostalim znanstvenim područjima, kao što su psihologija i pedagogija, no unatoč respektiranju navedenih znanosti bavi se proučavanjem duhovne dimenzije te se po tome razlikuje od ostalih znanosti ${ }^{55}$. Sudionici koji su dolazili na hagioterapijske grupe manifestirali su probleme u ponašanju koji se kreću u spektru od eksternaliziranih pa sve do internaliziranih problema u ponašanju. Promatrajući njihovu duhovnu dimenziju, elementi hagioterapije koje su sudionici procijenili najučinkovitijima jesu oprost, kajanje, osvještavanje vlastite vrijednosti, sloboda te promišljanje kroz meditaciju. Hagioasistent bio je poticatelj promjene te nije promatran samo kao prenositelj pozitivnih ideja nego i kao prenositelj duhovne stvarnosti koju zapravo živi te je na taj način i prenosi na osobu koja je došla po pomoć. Veliku ulogu u uključivanju sudionika u hagioterapijske tretmane imale su bližnje osobe, koje su bile žen-

54 Eric Kandel, In search of memory The emergence of a new science of mind, W.W. Norton \& Company.New York, 2006.

55 Tomislav Ivančić, Dijagnoza duhoune duše i hagioterapija... 
skog spola. Trenutak oporavka, okidač promjene na pozitivno, ostao je „neuhvatljiv“ i teško mjerljiv, što govori u prilog tezi kako čovjekove duhovne dimenzije možemo mjeriti isključivo kroz posljedice na ostalim čovjekovim dimenzijama, to jest na fizičkoj i psihičkoj razini.

Jedno od ograničenja ovog istraživanja odnosi se na relativno mali uzorak sudionika. Uz to, iako je cilj rada bio utvrditi elemente hagioterapije koje sudionici procjenjuju učinkovitima za osobni rast, razvoj i promjenu, dodatna vrijednost istraživanju mogla bi biti uključivanje drugih pojedinaca iz njihovog mikrosustava u samo istraživanje. Kako bi se što bolje utvrdila učinkovitost hagioterapijskog pristupa u budućim istraživanjima, bilo bi vrijedno povećati uzorak sudionika, uvrstiti neke od objektivnih instrumenata istraživanja te pratiti ispitanike longitudinalno, u više točaka mjerenja. Usprkos navedenim ograničenjima, ovo istraživanje jedno je od rijetkih u Hrvatskoj koje donosi nove spoznaje o duhovnosti kao zaštitnom čimbeniku za mentalno zdravlje pojedinaca.

\section{SELF-ASSESSMENT OF PERSONS WITH BEHAVIOURAL PROBLEMS ABOUT THE EFFECTIVENESS OF HAGIOTHERAPY}

\section{Summary}

In an increasing number of scientific researches, spirituality, religion, and religiosity are cited as a powerful protective factor for mental health, prevention, and treatment of behavioural problems as well as for contributing to the general health of the individual. The aim of this research was to get insight into hagiotherapeutic spirituality and to determine which elements of hagiotherapy, for people with behavioural problems involved in treatment, are assessed as effective. The research used a qualitative methodology and the data were analysed by thematic analysis. In-depth interviews were conducted with 6 participants of both sexes involved in hagiotherapy. In addition to the many methods and techniques generally used in advising people with behavioural problems, participants pointed out hagiotherapeutic approaches based on forgiveness, contrition, focus on the "good", freedom and human value, and meditation.

Key words: behavioural problems, hagiotherapy, spirituality, protective factors 